\title{
THE ENGLISH COMMON LAW CONCERNING MONOPOLIES
}

\author{
WiLliaM L. LETWIN†
}

I

T HAS BEEN WIDELY BELIEVED that the common law always favored freedom of trade. When English and American judges during the eighteenth and nineteenth centuries decided cases against monopolists, engrossers, or restrainers of trade, they thought they were continuing a tradition that reached back into "time of which no man hath memory." The congressmen who drafted and passed the Sherman Antitrust Law thought they were merely declaring illegal offenses that the common law had always prohibited. Those judges and legislators, like other lawyers, must have known, or at least would not have doubted, that the common law rules on these subjects had changed in the course of time, for it is taken as axiomatic that the common law "grows." But it is not always recognized that the common law can change its direction, and without much warning begin to prohibit practices it had formerly endorsed, or to protect arrangements it had earlier condemned. Lawyers do not so readily see that the common law at any given time reflects the economic theories and policies then favored by the community, and may change as radically as those theories and policies. As a result they have too easily accepted the mistaken view that the attitude of the common law toward freedom of trade was essentially the same throughout its history.

But the common law did not always defend freedom of trade and abhor monopoly. For a long time it did quite the opposite: it supported an economic order in which the individual's getting and spending were closely controlled by kings, parliaments, and mayors, statutes and customs, and his opportunities limited by the exclusive powers of guilds, chartered companies, and patentees. The common law first began to oppose this system of regulation and privilege at the end of the sixteenth century; it did not do so wholeheartedly until the eighteenth century; and by the middle of the nineteenth century, it had again lost its enthusiasm for the task. It would have been surprising if the pattern of development had been different. Changes in the conmon law are changes in the attitudes of judges and of lawyers; it would have been remarkable if they had persistently opposed monopoly when the rest of the community did not know

$\dagger$ Research Associate, University of Chicago Law School. 
the word and considered the phenomenon natural or desirable. It would have been strange if lawyers had upheld laissez-faire policies centuries before any statesman or economist had advocated or stated them, and had continued following them long after they had been abandoned or denied by the rest of the community. In fact, English laws governing monopoly and English policies for the economic organization of society changed together, except for minor differences in timing. The English law of monopoly traditionally includes four branches: the law on monopoly proper, whether by patent, charter, or custom; on forestalling, engrossing, and regrating; on contracts in restraint of trade; and on combinations in restraint of trade. These branches, distinct in form and based on more or less independent bodies of precedent, nevertheless show the same development from an active support of monopolies in the earliest period, through active opposition during an interlude of less than two centuries, to the leniency and indifference which characterized them in 1890.

The idea that the common law opposed monopolies from the earliest time onward was invented largely by Sir Edward Coke, ${ }^{1}$ who argued that monopoly was forbidden by the Civil Law, ${ }^{2}$ and implicitly by Magna Carta $^{3}$ as well as by certain statutes of Edward III's reign. ${ }^{4}$ But the earliest common-law precedent he could mention was a case that arose during the fourteenth century, and the modern lawyers and historians who follow his authority continue to cite that case as evidence of the ancient antagonism of common law to monopolies. ${ }^{5}$ Yet the case gives at least equally good evidence to the contrary. One John Pecche had a patent giving him the exclusive right to sell sweet wines at retail in London, and the Parliament of 1376 petitioned that he be punished for the flagrant use he had made of his privilege, "to the great damage and oppression of the people." $\mathrm{Had}$ this been an action to suppress and punish monopoly, it would tend to justify the theory that Coke put forward. But the fact that Pecche, who had a monopoly, was punished, does not mean that he was punished for having the monopoly.

1 Wagner, Coke and the Rise of Economic Liberalism, 6 Econ. Hist. Rev. 30 (1935).

2 See Coke's argument in Davenant v. Hurdis, Moore* $576,{ }^{*} 580$ (K.B., 1599).

32 Coke, Institutes $47,62-63 ; 3$ ibid., at c. 85.

4 ibid., at c. 85 .

53 ibid., at 181 ; 11 Co. Rep. ${ }^{* 53}$, *88a, b. Cf. 4 Holdsworth, History 344 n. 6 (1924). The case was cited in the same sense by Laurence Hyde during the parliamentary debate on monopolies in 1601. Tawney and Power, 2 Tudor Economic Documents 275 (1924).

- Rotuli Parliamentorum, 50 Edw. III, No. 33 (1376). 
Pecche came by his patent during the last years of Edward III's reign, when the King was too old to rule actively, and his heir, the Black Prince, was too ill. Another son, John of Gaunt, Duke of Lancaster, was therefore virtual ruler of England from about 1370 to 1377 . He hoped to succeed his father, but until that happy time came he intended to make the best of his position, and so he set out to increase his fortune. His chief agent in this venture was Richard Lyons, a merchant and alderman of London, who apparently financed Gaunt, in return for which the Duke gave or sold economic privileges to him and to his associates. ${ }^{7} \mathrm{John}$ Pecche, merchant, alderman, and once mayor of London, ${ }^{8}$ was among the associates favored. In 1373, "by the assent and aid of Richard Lyons," he was given letters patent permitting him and his deputies to sell sweet wines at retail in London, notwithstanding an ordinance of Parliament prohibiting retail sale of sweet wines throughout the realm. ${ }^{10}$ In return for this exclusive privilege, ${ }^{11}$ he was to pay the King a fee of 10 shillings on each pipe of wine he sold. ${ }^{12}$ The King further endorsed the grant by sending writs to the Mayor and Sheriffs of. London commanding them to give Pecche every assistance in exercising his monopoly, and ordering the Mayor to set a reasonable price for the wine. ${ }^{13}$ Nor did the Mayor and Aldermen of London seem to object in principle to the monopoly; in fact Pecche asserted that they had approved it before he put it in practice. ${ }^{14}$ Needless to say, they denied it in Parliament, but however they may have felt about Pecche's privilege, they were not generally averse to monopoly: only a few years earlier they had leased to Lyons the three taverns reserved for the sale of sweet wines, at an annual rent of $£ 200,15$ - which suggests that they did not object to monopolies that paid them good returns.

7 Trevelyan, England in the Age of Wycliffe 10-12 (1915 ed.). For details on Lyons, see Sargeant, The Wine Trade with Gascony, in Unwin (ed.), Finance and Trade under Edward III, 297-98 (1918).

1 Riley, Memorials of London 308; 2 ibid. 390 (1868).

- Rot. Parl., 50 Edw. III, No. 33 (1376).

${ }^{10}$ The patent is missing from the Calendar of Patent Rolls, but is given in the Calendar of Letter Books of the City of London, Letter Book G, 318 (Nov. 30, 1373). The prohibitory ordinance of Parliament seems to be missing both from Rot. Parl. and Statutes of the Realm, but is referred to in Rot. Parl. when repealed (cf. note 21 infra) as well as in the patent.

"2 Exclusive only in London; John Beverle had a similar license for Boston, Lincoln, Staunford, and Grantham. C.P.R., 48 Edw. III, 414 (March 5, 1374).

12 Rot. Parl., 50 Edw. III, No. 33 (1376).

${ }^{23}$ Letter Book G, 318 (Dec. 13, 1373); ibid., at 320 (Dec. 11, 1373).

14 Rot. Parl., 50 Edw. III, No. 33 (1376). Letter Book H, 38-40 (Aug. 1, 1376).

${ }^{15}$ Letter Book G, 199 (Aug. 26, 1365). 
For three years Pecche worked his monopoly in peace. But John of Gaunt became less popular than ever, encountering increased opposition from those who preferred that the Black Prince's son, Richard, should succeed Edward, from the Church, because he sponsored Wycliffe, and from the Londoners, who hated his arrogance and showed their antagonism finally by burning his palace during the Rebellion of 1381 . When Parliament met in 1376, it therefore attacked Gaunt, but indirectly, by accusing his associates. It attainted Lyons for engrossing and raising the prices of "all the merchandise that came into England," William Lord Latimer for taking bribes and misappropriating funds, Alice Perrers, the King's mistress, for obstructing justice, ${ }^{16}$ and Pecche, for having fraudulently obtained and excessively exploited his patent, and for having failed to pay the King the required fees. Pecche was sentenced "to be imprisoned, to make fine and ransom to the King, and also to give satisfaction to the parties complaining of his extortionate prices."17 He spent only a short while in prison, ${ }^{18}$ was soon after given a pardon excusing him from all further penalties and from paying any outstanding license fees, ${ }^{19}$ and although his patent was not revoked, ${ }^{20}$ it lost its value when Parliament repealed the former prohibition so that thereafter anyone could sell sweet wine at retail. ${ }^{21}$

Pecche's case was an accident of contemporary politics rather than part of an already developed common-law tradition against monopolies. The ultimate object of the attack was Gaunt; his various agents were assailed on the most plausible pretexts available. Parliament could find no other form in which to accuse Pecche except that he had defrauded the King and charged the public unreasonable prices. The word monopoly was not' even mentioned in the accusation; it was unknown in England until over a century later. ${ }^{22}$ The legal concept then existing which came closest to the notion of monopoly was "engrossing"; Lyons was accused of engrossing,

${ }^{16} 2$ Longman, Life and Times of Edward III 251-54 (1869).

17 Rot. Parl., 50 Edw. III, No. 33 (1376).

18 It cannot have been long, for Parliament met on April 24, 1376 and Pecche was released from the Tower on an order of mainprise dated July 26; Calendar of Close Rolls, $50 \mathrm{Edw}$. III, 437 (1376).

${ }^{19}$ C.P.R., 51 Edw. III, 448, 457 (April 10, 1377).

${ }^{20}$ As Wagner, op. cit. supra note 1 , at 41 , points out, following Gordon, Monopolies by Patents 231, n. (1897). Both, however, overlooked the condition that made revocation unnecessary.

${ }^{21}$ Rot. Parl., 50 Edw. III, No. 14 (1376). Cf. C.C.R., 51 Edw. III, 529 (Feb. 18, 1377).

22 It was first used, according to Fox, Monopolies and Patents 24 (1947), by Thomas More in 1516. 
but Pecche could not be accused of it because he had acted under royal license. Parliament did not question the King's right to grant such patents; indeed a judge during the same reign declared that the King might grant privileges "even though, prima facie, they appear absolutely against common right." ${ }^{23}$ There was as yet no basis at common law for holding a grant void because it created a monopoly.

The great movement against the granting of monopolies by letterpatent began only at the end of the sixteenth century, although it was so strongly supported that within less than a hundred years the principle had been established that Parliament alone could grant a monopoly, and that generally even it could not, as the King had regularly done, sell a patent or award it on a whim or as a friendly gesture. By the end of the seventeenth century the royal letter-patent had been converted into a more or less modern version of the patent, justifiable only by a solid contribution to economic development. The process was not, however, moved by coherent opposition to monopoly; it was brought about mainly by disturbances within the monopolistic system administered largely by the guilds, and by objections not to the broad economic effect of monopolies but to the political power which the crown exercised in granting them.

The first recorded case on monopolies was Davenant v. IIurdis, or The Merchant Tailors' case decided in 1599, ${ }^{24}$ which shows not only the extent of monopolistic control that the guilds exercised, but also the ends that such controls were supposed to serve, and the collisions that were taking place between several guilds, as each tried to maintain intact its power over a trade. The case arose under a by-law passed by the London tailors' guild in 1571, titled "An Ordinance for Nourishing and Relieving the Poor Members of the Merchant Tailors Company." The ordinance begins with a noble preamble, "Forasmuch as it is the duty of every Christian society to help and relieve every willing labouring brother in the Commonwealth, and especially such as are incorporated, grafted, and knit together in brotherly society ...,",25 and goes on to require every merchant who belongs to the guild and sends cloth to be finished by outside labor to have at least half the work done by fellow members of his guild.

The ordinance is a sign that the Merchant Tailors Company had lost control of the cloth-finishing trade. Its members, according to the charter of 1502 , were permitted to practice any art connected with the making of men's apparel, ${ }^{26}$ but the members of the Clothworkers Guild, incorporated

\footnotetext{
${ }^{23}$ Year-Book, 40 Edw. III, Pasch., pl. 8 (ff. 17-18).

25 1 Clode, Early History of the Guild of Merchant Taylors 393-94 (1888).

${ }^{26} \mathrm{Ibid}$., at 198.
} 
about $1530,{ }^{27}$ had overlapping rights. It therefore became a constant question whether any fuller or shearman was to belong to the Tailors or Clothworkers, whether his work was to be approved, his prices set, and the number of his apprentices regulated by the one company or the other. The dispute led to rioting in the streets of London, litigation, and requests that Parliament settle the matter by legislation. ${ }^{28}$ It led also to the Tailors' by-law, the need for which reflected the Tailors' weakness and also the decay of the entire system of guild regulation. The system presumed that each trade would be regulated by its own guild, but with increasing specialization of labor it became more and more difficult to define the limits of 'a trade or to keep the guilds from splitting into smaller units. There were disputes within disputes: at the very moment that the Tailors were fighting the Clothworkers, the fullers and shearmen who made up the latter company were quarreling over the power to set the price of "rowing"- the fullers insisting that it should be theirs alone, while the shearmen claimed it as theirs by custom. ${ }^{29}$ The conflicting interests of related but distinct trades led the Feltmakers to separate from the Haberdashers, and the Glovers from the Leather-sellers. Competition between the guilds led fourteen smaller guilds to petition the government of London to restore the old system whereby "in ancient times the company of artificers or handicraftsmen of the city had reserved the only use, trade, or exercise of their several arts and handicrafts," ${ }^{30}$ but the petition was never granted because the Aldermen of London could not restore the economic conditions that had made the guild system possible. One by-product of this general decay was the ordinance in which the Tailors, with a disarming appearance of fairness, decreed that half of the cloth-finishing done for its members must be done by its members.

In Davenant v. Hurdis, ${ }^{3 \mathrm{I}}$ the by-law was tested. Davenant, a clothmerchant of the Tailors' company, had sent out twenty cloths to be finished, but refused to give an equal number to members of his guild, and was assessed a fine of 10 shillings per cloth, as the by-law provided. $\mathrm{He}$ refused to pay, whereupon the Company instructed Hurdis, its beadle, ${ }^{32}$ to take from Davenant goods equal in value to the fine. Davenant brought

27 Unwin, Industrial Organization in the 16th and 17th Centuries 40-45 (1904).

23 Clode, op. cit. supra note 25 , at $199-203$.

29 Clothworkers' Court Book, April 8, 1567, in Unwin, op. cit. supra note 27, at 231.

ao Unwin, The Gilds and Companies of London 262 (1938 ed.).

"11 Moore *576 (K.B., 1599).

32 Clode, op. cit. supra note 25 , at 81 . 
an action of trespass, and Edward Coke, then Attorney General, appeared for him. Coke questioned the authority of the Tailors to make such a bylaw or to distrain for the fine, but his principal arguments were that the by-law was unreasonable, and contrary to law. It was unreasonable, he maintained, because it absolutely required the merchants of the company to give their business to the clothworkers, but did not require the latter to provide quick service, good workmanship, or reasonable prices for this business; as a result the merchants might be "utterly impoverished and forced to deceive their customers." nopoly: the same authority that gave the Tailors' Company power to make by-laws keeping half of cloth-dressing to their members would justify them in gradually appropriating the whole of the trade to their own sole use, until finally there would be no cloth-dressing except at their pleasure, and all other clothworkers would be unemployed and live on relief. ${ }^{34}$ Coke concluded that a by-] .w which if extended would give such monopoly powers and bring about such results must be against the public good, and cited precedents to prove that it must therefore be void. But the curious collection of authorities to which he appealed demonstrates how difficult it was to find a traditional basis in common law for the position he was taking. He could merely cite a number of cases in which bylaws or patents were held valid because they were for the public good: a regulation that all ships must harbor in one port and no other, a grant by the King giving a skilled foreigner the sole right to make sailing canvas, and another giving a skilled projector exclusive right to drain lands, a bylaw that all cloth sold in London must first be inspected and passed at Blackwell Hall, a by-law of St. Albans requiring each inhabitant to pay a contribution toward cleaning the town, and by-laws for the maintenance of bridges, walls, and similar public works. From these instances, Coke concluded: "but by-laws that establish monopolies are against common law and void." Yet the only direct authority that he offered for this rule was a text from the Civil Law, ${ }^{35}$ though he himself maintained that the Civil Law was not authoritative in English courts..$^{36}$

It was against just this weakness in Coke's argument that Francis Moore, attorney for Hurdis, made his principal attack. He conceded that laws ought to be for the public good and that the by-law in question

${ }^{33}$ Moore *576, *580-81 (K.B., 1599).

"Ibid., at *579-80.

${ }^{25}$ Tbid., at * 580 .

282 Coke, Institutes 98 (1797). See Wagner, The Common Law and Free Enterprise: An Early Case of Monopoly, 7 Econ. Hist. Rev. 217, 218 (1936). 
would be void if it created a monopoly. But he denied that it did so, for the by-law did not prohibit any clothworker from using his trade since it regulated the disposal of only a fraction of the business. Moreover, he continued, "if this by-law were really a monopoly, then all the privileges and customs of cities and boroughs, tending to exclude foreigners and to give the sole trading within the city or borough to its own freemen, could be called monopolies and illegal; from which would ensue the decay of all cities and boroughs in the realm ... which until this day have never been disallowed as monopolies against law and common right." 37 This argument, telling as it was against Coke's assertion that restrictive ordinances were bad at law, failed to convince the judges, who unanimously held that "a rule of such nature as to bring all trade or traffic into the hands of one company, or one person, and to exclude all others, is illegal.".38

The decision represented an innovation in the law as much as in economic policy. There is no reported common-law case on monopoly prior to Davenant v. Hurdis; Coke later mentioned in Parliament some unreported cases, ${ }^{39}$ but their precise content is unknown. The willingness of Francis Moore, Hurdis' attorney, to concede that a monopoly would be void at common law does not necessarily indicate that the legal principle was well-established; it may, rather, show the intensity of public opposition to monopolies, in which Moore shared. ${ }^{40} \mathrm{~A}$ number of prior cases are known, but these were heard in the Star Chamber, Privy Council, and other prerogative courts, which generally defended such monopolies as proper exercises of the King's power. ${ }^{41}$ The law was still so divided on the validity of monopolies as late as 1624 that Parliament felt it necessary to include in the Statute of Monopolies a provision that "all monopolies ... and the force and validity of them and of every of them, ought to be and shall be forever hereafter examined, heard, tried and determined by and according to the common laws of this Realm and not otherwise." 42

${ }^{37}$ Moore *576, *587 (K.B., 1599).

${ }^{38}$ Ibid., at *591: "prescription de tiel nature de inducer sole trade. . . ." ."Prescription" does not seem to be used here in its specific technical sense.

${ }^{30} 1$ House of Commons Journal 555 (March 15, 1621), 606 (May 3, 1621). Fox, op. cit. supra note 22, at 119 , cites three cases before Davenant $v$. Hurdis "in which monopoly grants were considered by the courts of common law." Of these, the case of John the Dyer did not concern a grant of monopoly (see pages 373-74 infra) and Hasting's case, Noy ${ }^{*} 182$, and Humphrey's case, Noy *183, [both mentioned in Darcy v. Allen, Moore *673 (1603)], were tried in the Exchequer.

${ }^{40}$ In 1597 Moore introduced a motion in Parliament against monopolies and was chairman of the committee to which the motion was referred. 2 Cheyney, A History of England from the Defeat of the Armada ... 296 (1926). He also participated in the debates of 1601. 2 Tudor Economic Documents 274 (1924).

${ }^{11}$ Fox, op. cit. supra note 22, at 119 et seq.

1220 Jac. I, c. 3 (1624). 
The next step, and perhaps the greatest single one, in creating the modern common law on monopolies was Darcy v. Allen, or The Case of Monopolies, ${ }^{43}$ decided in 1603 . Where Davenant v. Hurdis established that a corporate by-law was invalid if it created a monopoly, Darcy v. Allen went further, and laid down the principle that even a royal grant by patent would be invalid if it did so. Queen Elizabeth granted Darcy, her groom, a patent for a monopoly of the manufacture and importing of playing cards. ${ }^{44}$ In 1601, soon after Elizabeth issued her proclamation on monopolies, Allen, a London haberdasher, made and sold some playing cards, and Darcy brought an action of infringement. The Court of King's Bench unanimously held the patent void.

They held it void as a "dangerous" and "unprecedented" innovation, apparently because no other patent of this sort had previously been issued under the Great Seal. They held it void although it had undoubtedly been granted by the Queen, but in order not to attack royal prerogative directly, they adopted the fiction that "[t]he Queen was deceived in her grant; for the Queen, as by the preamble appears, intended it to be for the weal public, and it will be employed for the private gain of the patentee, and for the prejudice of the weal public." It prejudiced the public good by raising the price and lowering the quality of playing cards, but even more by depriving various workmen of a living. In explaining this main objection, the court said that

All trades, as well mechanical as others, which prevent idleness (the bane of the commonwealth) and exercise men and youth in labour for the maintenance of themselves and their families, and for the increase of their substance, to serve the Queen when occasion shall require, are profitable for the commonwealth and therefore the grant to the plaintiff to have the sole making of them is against the common law and the benefit and liberty of the subject. ${ }^{45}$

In short, Darcy's patent was held void on the argument that it yiolated the right of others to carry on their trade.

If the common law recognized each man's right to work at a lawful trade, as the courts of this period became fond of asserting, that right was neither simple nor absolute. Its basis was the feeling that a man should not be denied the means to earn a living: he and his family ought not to starve, his neighbors ought not to be burdened by supporting him, and the

411 Co. Rep. ${ }^{*} 84$, Moore $* 671$ (K.B., 1599), Noy *173. 'These reports are collated in Gordon, op. cit. supra note 20, at 193-232.

4 The patent was originally awarded in 1578, passed through several hands, and was granted to Darcy in 1598. Cheyney, op. cit. supra note 40 , at 307-8.

${ }^{45}$ Gordon, op. cit. supra note 20 , at 226. 
Crown should not be deprived of his contribution to the nation's wealth and power. This right to work was defended by statute and proclamation against foreign competition. A typical statute of this sort, the "Act against Strangers Artificers," passed in 1484, ${ }^{46}$ recited the complaint of certain English craftsmen that they were "greatly empoverished" and "likely in short time to be utterly undone for lack of occupation" because of foreign competition, and proceeded to limit importation of certain goods. This sort of protection of domestic workmen was enforced before this time, ${ }^{47}$ and after: even toward the end of the seventeenth century, royal proclamations were issued to prevent the importation of rope, hats, knives, gloves, locks, and paper. ${ }^{48}$ The common-law right to work was predicated on an economic system that would protect the established trades from competition, whether from foreign workmen, improperly qualified English workmen, overly aggressive guilds, or domestic monopolists. The right to work was protected by giving each guild a monopoly, and Darcy's grant was condemned not because it was a monopoly and therefore necessarily bad, but because it was a bad monopoly.

While the law prior to the eighteenth century supported every man's right to follow his trade, it also strictly limited and regulated this right. The nature of such controls is well illustrated in the third leading case on monopolies decided before the Statute of 1624, the Ipswich Tailors' case of 1614..$^{49}$ The tailors' guild of Ipswich had a by-law forbidding anyone from practicing his trade in the town unless he had served his apprenticeship under the Company or had been given its approval. They brought suit against one Sheninge for breaking this rule, but the court held that the by-law was invalid, because "at the common law, no man could be prohibited from working in any lawful trade. ..." In order to reach so broad a conclusion, the court must have closed its eyes to a series of customs and statutes-of great age. The right to follow any lawful trade was qualified, for one,thing, by the need to have served an apprenticeship-this condition was imposed not only by guild regulations, dating as far back as the thirteenth century in some cases, ${ }^{50}$ but also by the Statute of Artificers of 1562.51 That statute had not lost its force by 1614 , and despite the adverse

461 Ric. III, c. 12 (1483).

${ }^{47}$ E.g., 18 Hen. VI, c. 4 (1439), and Letter Book G, 130 (Feb. 23, 1362).

${ }^{48}$ Charles II, Proclamations (Nov. 20, 1661); ibid. (Feb. 20, 1675); James II, Proclamations (Apr. 29, 1687); ibid. (Aug. 14, 1687); Steele, Tudor and Stuart Proclamations (1910).

${ }^{49} 11$ Co. Rep. *53, Godbolt *252'(1614).

${ }^{50}$ Cf., e.g., early charters printed in Consitt, 1 The London Weavers' Company (1933).

si 5 reliz., c. 4 (1562). 
decision in the Ipswich Tailors' and subsequent cases, it was still followed at the end of the seventeenth century. ${ }^{52}$

The right to follow a trade was limited also by the rule that no man might work at several trades simultaneously. The validity of this rule was argued in the Ipswich Tailors' case, for the guild maintained that it rightly refused to approve Sheninge since he was already doing another kind of work. The court apparently decided that the common law did not prohibit this; it seems to have accepted Coke's statement that the prohibition was first introduced by a statute of 1363 , and that it was found so harmful that it was repealed in the following year. ${ }^{53}$ But Coke was mistaken. The law of 1363 to which he referred ${ }^{54}$ ordained, among other things, that each merchant should deal in only one sort of merchandise $e^{55}$ and "that Artificers, Handicraft People, hold them every one to one Mystery." "56 It may be true, as Coke says, that before this time the common law did not require each artisan to keep to his own trade. It is quite certain, however, that the prohibition was not repealed in the following year. Only the section which directed merchants to restrict their trade to one commodity was repealed; ${ }^{57}$ it would have been difficult to restrain a merchant who carried wool abroad from returning with wine, iron, or wax. The section which confined each workman to a single trade stayed in the books two hundred years more, and was indeed reinforced from time to time by specific acts such as that which forbade tanners to be shoemakers or shoemakers to be tanners. ${ }^{58}$ The legal principle on which the Ipswich Tailors depended and which Coke denied was not just a momentary aberration from a long-standing common-law tradition. The fact is that the monopolistic powers of guilds, which Coke insisted repeatedly were always void at common law, had really been supported by law. That support first

52 Francis Kiderby was indicted under the statute in 1669 , for setting up as a draper without having been apprenticed. He petitioned the Privy Council that the Crown might drop the prosecution, for, he said, "the Statute though not repealed yet, has been by most of the judges looked upon as inconvenient to Trade and to Encrease of Inventions." Nevertheless he felt sure that a common law court would find him guilty. His petition was granted. Privy Council Register (Oct. 29 and Dec. 17, 1669), quoted by Unwin, op. cit. supra note 27, at 252. Cf. Wade v. Ripton, 2 Keble *125, Siderf. $* 303$ (1666).

63 11 Co. Rep. $* 53, * 54$ (1614).

B 37 Edw. III (1363).

ss Thid., at c. 5.

$5738 \mathrm{Edw}$. III, c. 2 (1364), rejealed 37 Edw. III, c. 5 (1363).

"37 Edw. III, c. 6 was repealed by 5 Eliz., c. 4 (1564). 'The Act on tanners and shoemakers was 13 Ric. II, s. 1. c. 12 (1389). 
began to be withdrawn in the beginning of the seventeenth century, ${ }^{59}$ under the pressure of, among other things, Coke's powerful but inaccurate polemics.

There is no doubt that the series of cases at the turn of the seventeenth century radically changed the attitude of the common law toward monopolies. But it must be borne in mind that this change was also a consequence of the decay of the monopolistic system from within. Pecche was not attacked by irate consumers for raising his prices, but by irate subjects objecting to an unpopular minister. Similarly, Davenant v. Hurdis was not a dispute between a freedom-loving tradesman and a tyrannical guild as much as a conflict between two guilds for control of an industry. And Darcy v. Allen was not the action of a solitary champion bravely contesting the monopoly of a powerful courtier; it has been shown instead that Allen was supported in the case by the Mayor and Aldermen of London, who, regarding Darcy's patent as an attack on all the trades and privileges of the City, "comforted and animated [Allen] to continue his selling of cards" and promised to pay the costs of any. legal action that might follow. When Allen submitted a bill for his costs in defending himself against Darcy, the Mayor refused to pay, but Allen sued him and recovered.$^{60}$

Moreover, the mercantilist system of private and corporate monopolies, though very much weakened by 1600 , was still too widespread to be destroyed by the application of common-law remedies in specific cases. It was seriously limited, and in the end destroyed, by legislation. The first important law contributing to that result was the Statute of Monopolies of 1624 , which, however, has a deceptive ring. For though it was certainly directed against monopolies, it was based not on a preference for competition, but on constitutional objections to the power which the Crown presumed in granting monopolies and to the arbitrary reasons for which it had granted them. Parliament did not at this period oppose monopolies in themselves. As Bacon told the House of Commons in 1601, its attitude was inconsistent and suspect:

If her Majesty make a patent or a monopoly unto any of her servants, that we must go and cry out against: but if she grant it to a number of burgesses or a corporation, that must stand, and that forsooth is no monopoly. ${ }^{61}$

${ }^{39}$ They were still supported, for instance, in The Warden and Corporation of Weavers in London v. Brown, Cro. Eliz. *803 (1600), where the court held that Brown did not come under the weavers' control, for though he sold his goods in London, he wove them elsewhere; but the court added that this judgment did not question the guild's right to control weaving in London: "It were a good custom . . . being used time [immemorial]." Ibid., at 803.

${ }^{60}$ Davies, Further Light on the Case of Monopolies, 48 L.Q. Rev. 394 (1932).

o1 Prothero, Statutes and Constitutional Documents 112 (1906). 
This inconsistency the House of Commons carried over into the Statute of Monopolies, the first section of which declared void "all monopolies and all commissions, grants, licenses, charters, and letter patents heretofore made or granted, or hereafter to be made or granted to any person or persons, bodies politic or corporate whatsoever, of or for the sole buying, selling, making, working, or using of anything, or of any other monopolies"; the ninth section nevertheless provides that the Act shall not apply to any cities or towns, or any of their privileges, "or unto any corporations, companies, or fellowships of any trade, occupation, or mystery, or to any companies or societies of merchants within this Realm, erected for the maintenance, enlargement, or ordering of any trade of merchandise. . ." And this inconsistency, which symbolized Parliament's willingness to have monopolies, provided Parliament alone granted them, was not merely a matter of words in a statute. It justified the final irony in the case of Darcy v. Allen: only a few years after Darcy's monopoly of playing cards was judged void at common law, the same monopoly was given, under authority of the Statute of Monopolies, to the Company of Card Makers. ${ }^{62}$

The Statute of Monopolies soon put an end to the arbitrary granting of private monopolies. But it was not intended to abolish customary monopoly privileges of corporations. Cities and boroughs, guilds, and chartered trading companies continued to exercise their monopoly powers to exclude strangers from various trades. ${ }^{63}$ The common law continued to protect them, though with lessening fervor as the influence of economic liberalism grew, and some of these monopolistic controls were finally abolished only by legislation in the nineteenth century. ${ }^{64}$

\section{II}

Throughout these early monopoly cases the complaint is made that practices are objectionable because they tend to raise prices. But even this complaint did not arise from opposition to monopolies. It did not mean that the common law early in the seventeenth century favored competition or endorsed the determination of prices by the free play of the market. The common law favored "low" prices rather than free prices, and accepted as a matter of course that all important prices would be set by political or corporate authorities. The complaint meant only that Englishmen objected to private efforts to raise prices, and that they readily attributed a rise in prices to the evil machinations of profiteers. This super-

${ }^{62}$ Fox, op. cit. supra note 22 , at 128 n. 21.

63 Cases are voluminously noted in 32 Halsbury's Laws of England 345 n. 'o' (Hailsham's 2d ed., 1939).

4 Ibid., and see page 375 infra. 
stition was written into the early common law in the form of provisions against forestalling, regrating, and engrossing.

The body of law concerning these crimes has been thought to be an integral part of the law on monopolies because forestalling and the associated offenses seem at first sight to be older names for the modern monopolistic tactic known as "cornering the market"; and because since the seventeenth century, "engrossing" has become almost synonymous with "monopolizing." Jeffreys coupled the terms in this way when he gave his opinion in The East India Co. v. Sandys, ${ }^{65}$ and so did the authors of the Sherman Act when they explained the meaning of the word "monopolize" in the second section of that Act. ${ }^{66}$ But in fact the two bodies of law are quite distinct: they evolved from separate statutes, one did and the other did not raise questions of royal prerogative, and whereas the modern law on monopoly by patent was laid down early in the seventeenth century, that on forestalling did not take its present shape until almost two hundred years later. The basic legal difference is that the monopolist had a legal warrant for his activity, whereas the forestaller was justified by no custom, grant, or statute whatsoever.

Contrary to monopolies by patent, which always were and still are legal - the principal changes being in who gives and who may receive themforestalling was always illegal, and ceased to be so only when the crime was altogether abolished. "Forestalling" in the common law before the thirteenth century is said to have been an inclusive term for all unlawful attempts to raise prices. ${ }^{67} \mathrm{It}$ came to be a more particular term: in the year 1266 , the first statute prohibiting it defined forestallers as those "that buy anything before the due hour, or that pass out of the town to meet such things as come to the market." "68 "Regrating" meant simply retailing, buying in bulk and selling in small lots, and "engrossing," in its original narrow meaning, was to buy crops in the field before they were harvested or at least before they were ready to come to market. These offenses were indictable at common law, and various statutes assigned punishments ranging, according to the temper of the time, from fines and forfeiture to banishment and even death. ${ }^{69}$ Such statutes were passed periodically from

\footnotetext{
.."

6510 Howell's State Trials 372, 538 (1685): "though the word Monopoly, or Engrossing.

${ }^{66} 21$ Cong. Rec. 3152 (1890): "monopoly . . . is the sole engrossing to a man's self. ..."

${ }^{67}$ Illingworth, An Inquiry into the Laws . . . Respecting Forestalling . . . 14 (1800).

${ }^{68} 51$ Hen. III, § 6 (1266).

${ }^{69}$ Banishment from the town where forestalling was committed was imposed by a statute of uncertain date, probably prior to $1327 ; 1$ Statutes of the Realm 197, 202 et seq. [But cf. Winfield, Chief Sources of English Legal History 93 (1925).] Forfeiture was imposed by 25
} 
the thirteenth until the late seventeenth centuries, in some cases against the forestalling of certain specified commodities, in others against forestalling generally. But the application of these general statutes, as of the common law itself, was relatively narrow, and usually only the forestalling of food-or more precisely, of "dead victuals"-constituted a crime. One statute forbade engrossing of hides and oak-bark, ${ }^{70}$ and another, of cloth; ${ }^{71}$ but the fact that Parliament legislated for these commodities in particular argues that it did not consider them to be included under the general laws against forestalling. In a few scattered cases, also, courts found defendants guilty of forestalling land or houses, ${ }^{72}$ but here "forestalling" could only be brought in by stretching an analogy, for the offense was generally understood quite literally as buying commodities before they had been carried into the actual market place or before the market had officially opened. Perhaps the strongest evidence on the point occurs in Rex v. Waddington, ${ }^{73}$ one of the last important English cases of this type ${ }^{74}$ in which the defendant, having been charged with forestalling and engrossing hops, argued that his was no offense since hops were no victual, and the Court appeared to agree that if it had not been, there would have been no offense.

The major objective of laws against forestalling was to keep food prices low. Such laws fit very neatly into the more general price-fixing program administered by medieval and, later, mercantilist governments. Local authorities of manors, cities, and guilds had customary rights to control food prices; kings issued proclamations and parliaments passed statutes for the same end; all these are implicitly confirmed in a statute of 1533 which gave certain members of the Privy Council as well the right to set "reasonable prices" of "cheese, butter, capons, hens, chickens, and other victuals necessary for man's sustenance." 75 The work of surveillance would be much easier if all sales were made publicly in the market, and so forestalling and engrossing, means of evading the market, were seen as attempts to evade price-controls.

Edw. III, c. 3, $\$ 4$ (1350); death by 27 Edw. III, c. 11, $\$ 2$ (1353), repealed 38 Edw. III, c. 6, $\$ 1$ (1363).

701 Jac. I, c. $22, \$ \$ 7,19$ (1604).

${ }^{71} 1$ Phil. \& M., c. 7 (1554). Liber Albus 172-73 (comp. 1419, translated by Riley, 1861), is the case of a merchant fined by a London court for forestalling cloth; uncertain date prior
to 1419 .

72 Fof, Monopolies and Patents 21 n. (1947). $\quad$ "2 1 East *143 (1800).

"Sanderson, Restraint of Trade in English Law 97 (1926).

7525 Hen. VIII, c. 2, § 1 (1533). 
But to maintain low food prices was not the sole objective of the laws against forestalling. Just as monopolies by patent were attacked by those who feared to lose their own monopoly powers, so forestalling was abhorred not only by a public which hated high prices but also by those who saw in it an infringement of their privileges as owners of markets. Rights to hold markets were granted or confirmed by the Crown, and established local but powerful monopolies. What was given was not the mere right to hold a market, but an exclusive right. The extent of such privileges is illustrated in the case of the Abbot of Westminster ${ }^{76}$ The Abbot brought an action against one who sold cloth in London; William the Conqueror had given him a patent to hold a fair for thirty days, during which nobody should buy or sell merchandise at any other place within a radius of seven miles. The court presumably upheld the grant, and similar grants were upheld regularly. The owners of markets often had an intense interest in protecting their exclusive rights, for some of them had the right to charge a toll on certain goods sold in the market, and all of them were entitled to charge fees for market stalls put up on their land. To hinder sellers from coming to a market was therefore to deprive the owner of the market of stallage fees; thus the Prior of Coventry, in a suit against several who sold merchandise outside his market, declared that he thereby "Iost stallage, terrage and cottage, etc., wrongfully and to his damage."77

The objectives of statesmen and the interest of owners of markets coincided with the prejudices of the public. They considered forestalling, engrossing, and regrating the typical tricks of middlemen and speculators, and were convinced that merchants who used such tactics were parasites profiting by the distress of others. They could see nothing but evil and selfishness in such practices. Thus a commission of inquiry into forestalling in Suffolk in 1411 reported: Geoffrey Russell bought sixty quarters of barley at forty pence a quarter and sold them for twice as much; "John Cok and John Joye... secretly bought, in private and secret places, sixty quarters of wheat ... a quarter at eight shillings; whereas in open market, the same was sold for six shillings per quarter, \&c, and so the aforesaid John and John are common forestallers of corn"; and "Simon Basket... bought at Beccles, Owtehole, and Brompton, and in divers other places, forty quarters of wheat, of the price of six shillings per quarter, and conveyed the same coastwise into divers other parts, whereby the price of a quarter of wheat was raised to ten shillings . . . and so the afore-

\footnotetext{
${ }^{76}$ Registrum Brevium, f. 107. The case is cited in Darcy v. Allen, 11 Co. Rep. *84, Moore *671 (K.B., 1599), and East India Co. v. Sandys, 10 Howell's State Trials 372, 538 (1685).

${ }^{77}$ Year-Book 2 Edw. Ir, pl. 141 (1308).
} 
said Simon is a common forestaller." 78 The practices described show no sign of being; properly speaking, monopolistic; they appear on the contrary to have been acts of speculation, arbitrage, or wholesaling; but most men continued to identify the two phenomena until the new economic theory in the eighteenth century taught a few of them at least that speculation was no more profitable to the merchant than to the community at large, and that the community had as much to gain as the merchant from free trade.

The development of laissez-faire economic theory accounted for the abolition of the laws against forestalling. After 1552, when the great declaratory statute against forestalling was passed, ${ }^{79}$ the general prohibitions were reasserted periodically when food prices became unusually high. A Commonwealth Parliament passed a law in 1650 denying habeas corpus to defendants in any action concerning the buying or selling of foods, ${ }^{80}$ and William III issued a proclamation in 1698 insisting that the laws on forestalling be administered with full force. ${ }^{81}$ Another such occasion arose in 1766 when corn prices were particularly high. Many complaints were voiced, tumults and riots took place, "in which, as usual in popular commotions, great irregularities took place," many lives were lost, order was restored only after the militia was called out and a number of rioters sentenced to death and hanged. George III tried to improve things by issuing a proclamation to put in force the statutes against forestallers. But, The Annual Register noted, many doubted whether such action could be of any use: "It was apprehended that this measure would have an effect contrary to the intentions of the council, and by frightening dealers from the markets, would increase that scarcity it was designed to remedy."

The doctrine hinted at in this comment, that public regulation of the market would produce worse results than the free action of merchants, was still novel in 1766 but beginning to gain force. It dominated the committee of the House of Commons which reported in the following year "that the several laws relating to Badgers, Engrossers, Forestallers, and Regrators, by preventing the circulation of, and free trade in, corn, and

78 Plea Roll 12 Hen. IV, 6 (1411), quoted in Illingworth, op. cit. supra note 67, at 240-42. Why Cok and Joye should have committed a crime at high prices rather than trade legally at low must remain a mystery.

195 \& $6 \mathrm{Edw}$. VI, c. 14 (1552).

${ }^{80}$ Statute of Oct. 23, 1650, Firth and Rait, 2 Acts and Ordinances of the Interregnum 442 et seq. (1911).

"1 William III,YProclamation Oct. 13, 1698.

* Annual Register 39-40 (1767). 
other provisions, have been the means of raising the price thereof in many parts of this Kingdom." $\$ 83$ The report suggested that those laws should be abolished, and action of this sort was finally taken in 1772, when a bill was prepared, reported by Edmund Burke-who was the main exponent in Parliament of this measure-and quickly passed by Commons. ${ }^{84}$ The Act repealed the various statutes against forestalling because, as its preamble said, "it hath been found by experience that the restraints laid by several statutes upon the dealing in corn, meal, flour, cattle, and sundry other sorts of victuals, by preventing a free trade in the said commodities, have a tendency to discourage the growth, and to inhance the price of the same." 85 With the passage of this Act the cause of free trade seemed to be triumphant; the crime of forestalling had been abolished-so Blackstone, among others, thought ${ }^{86}$-and Adam Smith's remark, published three years later, that to fear forestalling was like fearing witchcraft seemed to be more useful as a contribution to public education than to practical policy. ${ }^{87}$

For a short while, however, the law against forestalling was revitalized by Lord Kenyon's decision in Rex v. Rusby. ${ }^{88}$ Rusby was indicted in 1799 for regrating thirty quarters of oats, and presumably rested his defense on the Act of 1772. Kenyon held, however, that "though in an evil hour all the statutes which had been existing above a century were at one blow repealed, yet, thank God, the provisions of the common law were not destroyed" 89 and found Rusby guilty at common law. The vigor of Kenyon's address against Rusby so inflamed the public that a mob of Londoners rioted, tried to lynch Rusby, and ended by pulling down his house $;^{90}$ the public was apparently not so convinced as Burke, Smith, and Parliament that forestalling was economically beneficial, or, at least, that laws prohibiting it were more harmful than the thing itself. After Kenyon's time, however, there were no further common-law prosecutions against forestalling, ${ }^{91}$ and to make quite sure, Parliament in 1844 passed a law repeal-

${ }^{83}$ House of Commons Journal (Apr. 8, 1767).

84 Ibid. (drafting committee appointed March 13, 1772, bill read May 6, passed May 20). For Burke's views on the subject, see his Thoughts and Details on Scarcity, 5 Works 133, 150 et seq. (Nimmo's ed., 1899).

8512 Geo. III, c. 71 (1772).

${ }^{86} 4$ Blackstone, Commentaries 159 (5th ed., 1773).

${ }^{87} 2$ Smith, Wealth of Nations 34-35 (Canaan ed., 1922).

88 Peake Add. Cas. ${ }^{*} 189$ (1800). $\quad{ }^{89}$ Tbid., at ${ }^{*} 192$.

${ }^{90}$ Barnes, History of the English Corn Laws 81-82 (1930).

${ }^{91}$ Sanderson, op. cit. supra note 74 , at 98 . 
ing all the remaining statutes against it, and utterly abolishing the common-law crimes of forestalling, engrossing, and regrating..$^{92}$

Clearly, then, the laws against forestalling and engrossing, which some have tried to identify as a fount of modern antitrust law, did not have the required character. They were of narrow scope, applying almost exclusively to trade in foodstuffs; they were part of a program to regulate all economic activities; like the common law against monopolies by patent, they were supported by monopolists-in this case, the owners of markets-who found them useful protection; and they were finally repealed by the supporters of free trade and in the name of free trade.

\section{III}

Because the Statute of Monopolies settled that branch of law into its present narrow concern with patents, and the Acts of 1772 and 1844 altogether did away with the law against forestalling, the only English tradition from which modern antitrust law could grow were the bodies of law against contracts in restraint of trade and combinations in restraint of trade. The manner in which those laws were interpreted during the nineteenth century, however, very much weakened their capacity for controlling modern monopolies.

The common law relating to contracts in restraint of trade stems from the Case of John Dyer, ${ }^{93}$ decided in 1414. The report of the case is meager. John was sued for breaking his bond not to practice the trade of dyeing in his home town for a half year; he apparently maintained that he had not broken his bond, and seems to have won the case. One of the judges suggested that John could have used the stronger defense of demurring at law, as the condition of the bond was illegal, and he continued in words which have become all too famous in the literature on monopolies: "By God, if the plaintiff were here he should go to prison until he paid a fine to the King." The case was an extremely powerful precedent until the beginning of the eighteenth century.

But for all its legal power, the Case of John Dyer does not demonstrateas so many have believed-that the common law always condemned restraints on trade. If one seventeenth century lawyer could cite the case as authority for that view, his opponent could counter with a much older

$27 \& 8$ Vic., c. 24 (1884). 4 Holdsworth, History 379 (1924), says that the forestalling laws were repealed by $6 \mathrm{Geo}$. IV, c. 129 (1825), under the influence of "the economists of the school of Ricardo." There is little evidence that Ricardo or his school particularly affected the pissing of the act of 1844, and the act of 1825 which Holdsworth cites has no bearing on forestalling, being instead a combination act. See page 381 infra.

s3 Year-Book 2 Hen. V, 5B (1414). 
precedent, the Case of the Archbishop of York, ${ }^{94}$ in which a court upheld the custom of the Archbishop's manor at Ripon that no one should operate a dyeing-house there without the Archbishop's license. If the common law is supposed to have been such an ardent protector of free trade, why was it prepared to uphold an Archbishop's power to keep a dyer from following his trade in Ripon forever, but not an ordinary man's power under a voluntary agreement to keep a dyer from following his trade in Dale for half a year?

The answer, of course, is that the common law prior to the fifteenth century did not favor free trade but reached its decision in John Dyer's case on quite different grounds. The restraining agreement in the Dyer's case was embodied in a bond, and it has been suggested that judges distrusted bonds because they were so often oppressive, and lost few opportunities to hold them void. ${ }^{95}$ Lord Macclesfield, in his famous opinion in Mitchel v. Reynolds, ${ }^{96}$ held that the issue was not so much whether the restraining agreement was by bond or by contract but whether it was based on a good and adequate consideration. Yet, as he understood John Dyer's case, the fact that it rested on a bond seemed material; "for suppose," he wrote,

(As that case seems to be) a poor weaver [sic], having just met with a great loss, should, in a fit of passion and concern, be exclaiming against his trade, and declare, that he would not follow it any more, etc., at which instant, some designing fellow should work him up to such a pitch, as, for a trifling matter, to give a bond not to work at it again, and afterwards, when the necessities of his family, and the cries of his children, send him to the loom, should take advantage of the forfeiture, and put the bond in suit; I must own, I think this such a piece of villainy, as is hard to find a name for. . . ${ }^{97}$

Lord Macclesfield evidently thought that no court should uphold an agreement made in such circumstances, and perhaps earlier common-law judges did too.

But the more important basis for deciding against the restraint in the Dyer's case was the principle, so important in the cases on monopolies by patent, of the individual's right to work. It may appear that to prevent a man from following one trade in one particular town for six months did not very seriously limit his right to work: he might take up another trade, or

9eg. Brev., f. 105. The two cases were confronted in Darcy v. Allen, op. cit. supra note 43 .

${ }^{95}$ Sanderson, op. cit. supra note 74, at 14. Cf. Clerk v. Taylors of Exeter, 3 Lev. 241 (1685), in which the Exchequer held that in all the previous cases on restraint of trade the agreement had been disapproved if by bond, approved if by contract (assumpsit).

$\$ 1$ Peere Wms. *181 (1711).

${ }^{97}$ Tbid., at 193. 
move to another town. But in the fifteenth century, those alternatives were not in fact open to him. In order to take up another trade, he would have had to pass through an apprenticeship of seven years, or with great difficulty and expense satisfy a guild that he was a master of its craft, and this remedy was for all practical purposes ruled out. Nor could he more readily practice his own trade in a new town, for the guilds and municipal corporations of each place had by-laws to prevent strangers-that is, anyone not free of the town or its guilds-from entering into competition with citizens. ${ }^{98}$ The whole guild system, therefore, made it nearly impossible for a tradesman to earn his living if he did not practice his own trade in his own town, and this was the main reason why, as long as the guilds maintained their power, contracts in restraint of trade were held void. To have done otherwise would have been to concur in arrangements by which men deprived themselves of their means of support. The power of the guilds to regulate entrance into trade had begun to weaken by the sixteenth century, although cities and towns retained fragments of such powers until 1835, when the Municipal Corporations Act finally gave anyone the right to keep any shop or follow any trade in any borough. ${ }^{99}$ It was with the decay of this power in the guilds that the law on contracts in restraint of trade came to change, and the time when the courts refused to uphold the restrictive powers of the Ipswich Tailor's guild was also the time when they first held valid a contract in restraint of trade. ${ }^{100}$

From then on, the law on the subject became more and more complex, since each case involved two contrary principles. On the one hand, the common law was inclined to uphold contracts in restraint of trade for the same reasons which moved it to sustain any good contract. To own property implied the right to dispose of property by contract, and if a reasonable man disposed of his property in a way which he considered good, it was not for the court to tell him he was mistaken. ${ }^{101}$ On the other hand, the

98 Cf. Sanderson, op. cit. supra note 74, at 15.

95 \& $6 \mathrm{Wm}$. IV, c. 76 (1835). London was not considered a borough under the Act, and cases to exclude "foreigners" from certain employments in London continued until later in the nineteenth century. 32 Halsbury's Laws 345 (1939).

100 Ipswich Tailors' case, 11 Co. Rep. *53 (1613); Rogers y. Parrey, 2 Bulst. *136 (1614). In the earlier cases, the restraints were held void, John Dyer's case being cited as authority for each: Anon., Moore *115 (K.B., 1578) - a mercer's apprentice bound himself not to exercise his craft for four years in Nottingham; Anon., Moore *242 (K.B., 1587), 2 Leonard *210-a blacksmith bound himself not to practice the trade in South-mims; Colgate v. Bacheler, Cro. Eliz. ${ }^{*} 872$, Owen. $* 143$ (1601) - a haberdasher gave bond not to trade in Canterbury or Rochester for four years, of which Anderson, J. said that "he might as well bind himself, that he would not go to Church."

${ }^{101}$ Jollife v. Broad, 2 Roll. Rep. 201, Cro. Jac. ${ }^{* 596,1} 1$ Wm. Jones 13 (1620): Restraint ancillary to sale of a mercer's business in Newport held void in Common Pleas, reversed in 
common law was inclined to invalidate contracts in restraint of trade because they deprived a man of the means to earn a livelihood, ${ }^{102}$ or because they deprived the public of the advantages of competition. ${ }^{103}$ The first of these reasons prevailed until the eighteenth century, the second slowly replaced it. The conflict of these principles, and their application to the particular circumstances of each case, have resulted in the general rule, still true today, that some contracts in restraint of trade are good and others are bad. The basis on which the distinction should be made was first formally stated in Mitchel v. Reynolds, decided in 1711; it was stated in broader terms - or as some think, changed-by the decision in Nordenfelt v. Nordenfelt in 1894.

In Mitchel $v$. Reynolds ${ }^{104}$ the defendant assigned to the plaintiff the lease of a bakery in a certain parish of London for five years, and undertook to pay the plaintiff $£ 50$ damages if he should work as a baker within that parish during those five years. The plaintiff brought suit for the damages, and though the defendant pleaded that since he had served his apprenticeship as a baker and had been admitted to the guild no private person could lawfully prevent him from working at that trade, Chief Justice Parker (later Lord Macclesfield) found for the plaintiff. The fame and great interest of this case is not in the decision, but in the opinion, for there Lord Macclesfield very systematically classified all restraints of trade and arrived at his long-lasting rule for distinguishing good restraints from bad. He first divided all restraints of trade into involuntary or voluntary; the contract in issue was clearly a voluntary restraint. Among voluntary restraints he distinguished between those "where the restraint is general not to exercise a trade throughout the kingdom, and where it is limited to a particular place." General restraints, he held, had always been held void, and should be, "being of no benefit to either party, and only oppressive." ${ }^{105}$ But particular restraints are of two sorts: without consideration, "all of which are void by what sort of contract soever created," and Macclesfield here cited the Dyer's case as evidence for this point; and with consideration. Macclesfield's rule, therefore, was that a contract in re-

King's Bench, affirmed in Exchequer. Dodderidge, J. in K.B.: "It is the usual course of men in their old age to turn over their trade to another...."; 2 Roll. Rep. 201, 203. Similarly, Bragge v. Stanner, Palmer *172 (1621); Pragnell v. Goff, Style *111, Aleyn *67 (1648); Hunlocke v. Blacklowe, 2 Wms. Saunders *156, 2 Keble *674 (1670).

${ }^{102}$ See the cases listed at note 100 supra. Also Ferby v. Arrosmyth, 2 Keble *377 (1668).

${ }^{103}$ See the cases listed at note 108 infra.

1041 Peere Wms. *181 (1711).

105 Ibid., at $* 182$. 
straint of trade can be good only if the restraint is particular and the contract "appears to be made upon a good and adequate consideration, so as to make it a proper and useful contract." ${ }^{106}$ Lord Macclesfield had discovered this much from precedent, but being a lawyer of his time, he was interested to show not only what the law was, but also the reasonable explanation of why it should be so, and therefore he added:

[T] he true reasons of the distinction upon which the judgments in these cases of voluntary restraints are founded are, 1st, the mischief which may arise from them, 1st, to the party, by the loss of his livelihood, and the subsistence of his family; 2dly, to the public, by depriving it of an useful member. ${ }^{107}$

These mischiefs might arise from general restraints but could not from particular restraints; the latter were good because the parties might gain and the public lose nothing from them. Once a man could reasonably be expected to enter a new trade if he sold his last one, or to move to a new place if he bound himself not to trade in his former one, the law became quite willing to uphold fair contracts in which he bound himself to desist from competition within a limited area. And so the test became whether the contract was fair and the area to which it applied limited.

For at least a century, Macclesfield's rule was followed quite religiously. But then new problems in the interpretation of the rule began to enter: How important a consideration was public policy; if a contract did not injure either of the parties, might it still be bad because it interfered with competition? How large an area was "particular" rather than "general"; if the business of one party extended throughout the kingdom and real protection from competition could only be had by a "general" restraint, was a contract of this sort nevertheless to be held bad automatically? ${ }^{108}$ How was the word "reasonable," recurring so often in Macclesfield's opinion, to be interpreted; was the real test of a restraint whether it was reasonable, and was Macclesfield only enunciating a special case of the rule, valid for his time but not for always, when he held that particularity and consideration made a restraint reasonable and therefore good? All these questions were decided one way or another by judges during the nineteenth century and finally settled by the decision of the House of Lords in Nordenfelt $v$. Maxim Nordenfelt Guns and Ammunition Co., ${ }^{109}$ and particularly by the rule laid down by Lord Macnaghten.

${ }^{108}$ Tbid., at *185*86.

107 Mbid., at $* 190$.

108 See, e.g., Wickens v. Evans, 3 Y. \& J. *318 (1829); Wallis v. Day, 2 M. \& W. *273 (1837); Mallan v. May, 11 M. \& W. *652 (1843); Shrewsbury and Birmingham Railway Co. v. London and North-Western Railway Co., 21 L.J.Q.B. 89 (1851); and Tallis v. Tallis, 1 El. $\&$ Bl. *391 (1853).

109 [1894] App. Cas. 535. 
The case arose on a contract whereby Thorsten Nordenfelt agreed not to engage in the ammunition and armaments business, except in behalf of the Company; the restraint to apply for twenty-five years and in all countries. The Company brought action to enforce the covenant by injunction, and Nordenfelt successfully defended himself in the lower courts by arguing that the restraint was general and therefore void. The Court of Appeals reversed the lower court ${ }^{110}$ and Nordenfelt then appealed to the House of Lords. That body unanimously held that the restraint, though general, was valid because it was reasonable. Lord Macnaghten, in his concurring opinion, set down what has since been the governing rule in such cases; it very neatly coordinates the considerations of public policy, generality of restraint, and reasonableness:

The public have an interest in every person's carrying on his trade freely: so has the individual. All interference with individual liberty of action in trading, and all restraints of trade of themselves, if there is nothing more, are contrary to public policy, and therefore void. That is the general rule. But there are exceptions: restraints of trade and interference with individual liberty of action may be justified by the special circumstances of a particular case. It is a sufficient justification, and indeed it is the only justification, if the restriction is reasonable-reasonable, that is, in reference to the interests of the parties concerned and reasonable in reference to the interests of the public, so framed and so guarded as to afford adequate protection to the party in whose favour it is imposed, while at the same time it is in no way injurious to the public."11

Only the greatest optimism could have made it appear to Lord Macnaghten that contracts in restraint of trade are at all likely "to afford adequate protection" to a party and at the same time to be "in no way injurious to the public." What makes this entire area of law so difficult is precisely that the interests of the restraining party and of the public are so often opposite. This problem indeed seems to be at the core of Nordenfelt $v$. Nordenfelt, although the court very tactfully covered it over. Vague references were made to the public interest, which was said not to favor or require Thorsten Nordenfelt's competition with the Company. On the other hand, a great deal was said about the Company's need for adequate protection. The Lord Chancellor took notice of the improved means of communication that had become available since Mitchel v. Reynolds, and argued that in these new conditions reasonable protection may mean worldwide protection; he decided that because the Company sold its armaments mainly to governments, considering "the nature of the business and the limited number of customers,"112 it needed protection of such width.

${ }^{110}[1893] 1$ Ch. 630.

III [1894] App. Cas. 535, 565.

112 Ibid., at 548-50. 
And Lord Watson, in his concurring opinion, made it quite clear why it was possible so readily to identify the public interest and the private interest of the covenantee:

[But] it must not be forgotten that the community has a material interest in maintaining the rules of fair dealing between man and man. It suffers far greater injury from the infraction of these rules than from contracts in restraint of trade.113

-This remark is the clearest possible indication that by 1894 English law on contracts in restraint of trade was not in any important respect an instrument for the maintenance of a competitive economic order. If ever, then only for a very short period after Mitchel $v$. Reynolds did the courts give the public policy of promoting competition an important part in deciding cases on contracts in restraint of trade. The decision itself in Nordenfelt $v$. Nordenfelt, the words in which Lord Macnaghten expressed his rule of reasonableness, and the dictum of Lord Watson, all declared that competition was no longer public policy, or at least that freedom of contract had become a more important end than freedom of trade. ${ }^{114}$

\section{IV}

The law on combinations in restraint of trade was by the end of the nineteenth century narrow and ineffective. Developments both in statute and common law joined to produce this result. The statute law governing combinations became increasingly lenient during the nineteenth century, in response to greater sympathy, abstract as well as sentimental, for the labor unions. The common law, influenced by a feeling that employers should not be denied rights granted to workers, matched the new legal power of the latter with a solicitous concern for employers' combinations; in the end it came to put a higher value on the freedom of entrepreneurs to use any means short of violence to outstrip competitors than on the right of the public to enjoy the advantages of competition.

Legislation governing wages and conditions of labor began with the Ordinance of Labourers passed in $1349,{ }^{115}$ which was confirmed and extended by numerous later statutes. In the sixteenth century, these occasional laws were consolidated in the great Elizabethan Statute of Artificers, ${ }^{116}$ which governed apprenticeship and wages, and in the Act of $1548,{ }^{117}$ which provided criminal penalties against any workmen who con-

113 Tbid., at 552.

114. Cf. Morris v. Saxelby, [1916] 1 App. Cas. 688, 699.

11523 Edw. III (1349).

1165 Eliz., c. 4 (1562).

1172 \& 3 Edw. VI, c. 15 (1548), confirmed by 22 \& 23 Car. II, c. 19 (1670). 
spired or agreed to raise wages or reduce hours of labor. But there was no thought in these statutes of making it possible for workmen to compete; on the contrary, the sixteenth century legislators who passed these laws to fix the terms and wages of labor hoped to recapture the economic stability that had been shaken by the Black Death, the movement of men from manors to towns, and the early industrial revolution. ${ }^{118}$ They wanted competition no more than they understood it. Although these laws, like others of the time, appear, in the light of later developments and interpretation, to express antagonism to monopolistic arrangements and approval of competition, they were really intended to reinforce the system of direct economic control.

The earliest instances of general labor legislation influenced by freetrade theories were the Combination Acts of $1799,{ }^{119}$ which prohibited combinations of workmen only, and the Combination Act of 1800,120 which superseded it and prohibited masters as well as workmen from combining. It has been said that these Acts were prosecuted more severely against combinations of laborers than against those of masters; it appears that they were not very effective at all; it is certain that they did not settle the problem of changing from a legally regulated labor market to a free one. ${ }^{121}$ Riots and violence continued as frequent inçidents of labor relations after 1800, and Place, Joseph Hume, McCulloch, and other radical followers of Bentham argued that this disorder would not cease until workers were given a legal right to combine. ${ }^{122}$ The Benthamites, besides, advocated a statute permitting workers to combine because this law was implied by two of their basic political principles. These, as Dicey has expressed them, were "the belief that trade in labour ought to be as free as any other kind of trade," and "the well-grounded conviction that there ought to be one and the same law for men as for masters; Adam Smith had, about fifty years earlier, pointed out that trade combinations on the part of workmen were blamed and punished, whilst trade combinations on the part of masters were neither punished nor indeed noticed."123 In the early decades of the nineteenth century, those who fayored freedom of trade tried to achieve their other aim of equality before law by giving workers as well as masters freedom to associate. By rejecting the alternative that would have

118 Nef, 1 Rise of the British Coal Industry 165-89 (1932).

11938 Geo. III, c. 81 (1799).

${ }^{120}$ Mbid., at c. 106 (1800).

121 George, The Combination Laws, 6 Econ. Hist. Rev. 172 (1935).

12 Robbins, The Theory of Economic Policy 106 et seq. (1952).

${ }_{23}$ Dicey, Law and Opinion in England 196 (1905 ed.). 
achieved both their objectives, by not denying the right of combination to workers and masters alike, they wasted an opportunity to secure economic freedom against attack by monopolies of either.

But in any case, so strong was the Benthamites' belief in freedom of association, so complete their inability to foresee the monopolistic position which labor unions and industrial combinations would in time achieve, so great their faith that if workers were allowed to combine in friendly associations they would desist from all violence and monopolistic activities, that in 1824 they successfully urged Parliament to pass the Act that gave combinations of workmen and masters alike immunity from all statutory and common-law prohibitions. ${ }^{124}$ Workmen proceeded to make the most uninhibited use of that immunity. In the next session of Parliament, Huskisson brought in a bill that reversed the terms of the Act of 1824: where the old Act had given immunity for everything but intimidation and violence, the new bill-which very soon became law-restored the power of the common law over combinations, and excepted only a limited right to combine. ${ }^{125}$ The pattern had, however, been established, and the increasing sympathy for the condition of workingmen excited by Tory reformers and early Socialists, among others, finally produced in 1871 the first Trades Union Act, ${ }_{2}^{126}$ and in 1875, a new Combination Act ${ }^{127}$-both of which had the effect of legalizing all combinations of workers and masters alike, provided those combinations were formed to settle labor disputes and to negotiate hours and conditions of labor.

The law on combinations where these were labor unions or employers' associations was dominated by the statutes on the subject. On the other hand, combinations of merchants to fix prices of goods, share out a market, or otherwise limit competition, were governed by no general statutes, particularly after the laws against forestalling were repealed, ${ }^{128}$ and therefore remained under the jurisdiction of common law. In a few instances, such combinations were indicted as criminal conspiracies at common law..$^{129}$ But after the beginning of the nineteenth century, the common law

1245 Geo. IV, c. 95 (1824).

1256 Geo. IV, c. 129 (1825). Cf. Dicey, op. cit. supra note 123, at 191 et seq.

- 2334 \& 35 Vic., c. 31 (1871).

$12738 \& 39$ Vic., c. 86 (1875).

128 See pages 372-73 supra.

${ }^{129}$ Rex. v. Journeymen Tailors of Cambridge, 8 Mod. *10 (1721); Rex v. Eccles, 1 Leach * 274 (1783); Rex v. Mawbey, 6 T.R. *619 (1796). Cf. Winfield, The History of Conspiracy and Abuse of Legal Procedure 111-17 (1921). 
came to regard an agreement between competitors to combine as analogous to a contract in restraint of trade, and judged such agreements by whether they left the parties reasonably free to act as they desired. All along, less attention was paid to whether the agreement seriously interfered with competition. In Hearn 0 . Griffin, ${ }^{130}$ decided in 1815 , the court upheld an agreement between two rival coach-owners to charge the same prices and provide no competing services; this, wrote Lord Ellenborough, "is merely a convenient mode of arranging two concerns which might otherwise ruin each other." In Wickens v. Evans, ${ }^{131}$ decided in 1829, three boxmakers had agreed to divide England into areas in which each was to be the exclusive seller. This arrangement was upheld on the grounds that it was only a partial restraint of trade, one of the judges maintaining that it was "not a monopoly, except as between themselves; because every other man may come into their districts and vend his goods: all they propose is, that they shall not carry on a rivalry. . . " In Hilton v. Eckersly, ${ }^{132}$ decided in 1855, the court refused to enforce an agreement between eighteen mill owners to settle wages and hours by majority rule. The reason given was that the parties were not left free to trade on their own terms; but the case was decided before the Combination Act of 1875 authorized such agreements. In Collins v. Locke, ${ }^{133}$ decided in 1879, an agreement between docking firms to distribute work and profits among themselves was upheld on the grounds that it did not unduly restrain the free action of the parties. But the modern common law on combinations in restraint of trade was established by the Mogul Steamship case, ${ }^{134}$ which laid down the principle that although a trade combination might be destroyed by attack from within, it could not be successfully attacked by an outsider.

The Mogul Steamship case was decided two years before the Nordenfelt case; these two are among the chief reasons for the subsequent inability of English common law substantially to deter the growth of monopolies. The defendants in the Mogul Steamship case were a number of shipping lines who had formed an association, and agreed to regulate by their joint decision the number of ships each would send to Hankow or Shanghai during the brief tea-export season, the division of cargoes between those

1302 Chitty 407 (1815).

1813 Y. \& T. 318 (1829).

1226 El. \& Bl. *47 (1855).

${ }^{223} 4$ L.R.A.C. 674 (1855). Cf. The Shrewsbury and Birmingham Railway Co. v. The London and North-Western Railway Co., 21 L.J.Q.B. 89 (1851).

${ }^{134}$ Mogul Steamship Co. v. McGregor [1892] App. Cas. 25. 
ships, and freight rates, to give a rebate to all shippers who dealt exclusively with members of the association, and to prohibit their agents in China from acting in the interest of competing shippers. Short of an outright merger or trust agreement, they could hardly have formed a more complete combination. The Mogul Steamship Company had been included in the association at first, were later excluded, but continued to send their ships to a Chinese port. The defendants retaliated by sending more of their ships to the port, underbidding Mogul rates, threatening to dismiss from their service agents who arranged to load Mogul ships, and circulating notices that they would not give their rebate to anyone who shipped by Mogul. 'The Mogul Company brought a suit for damages against the members of the association, alleging that they formed a conspiracy to injure Mogul interests. On the original action the Chief Justice, Lord Coleridge, judged for the defendants; ${ }^{135}$ this was affirmed by the Court of Appeals, three justices dissenting; ${ }^{136}$ and the plaintiff appealed to the House of Lords, which unanimously affirmed the decision. ${ }^{137}$

The principle on which all the justices agreed was that the agreement was unlawful in the sense that the courts would not enforce it, but that it was not "contrary to law."138 It would become an illegal conspiracy at common law only if it sought an unlawful end or used unlawful means; and since, as the Lord Chancellor put it, the combination had neither acted with any "malicious intention to injure rival traders," nor used any unlawful means, such as violence, intimidation, molestation, or inducing people to break contracts, it was innocent. ${ }^{139}$ There were indeed some qualms among the justices as to whether all the means were lawful, whether the threatening notices distributed by the defendants did not amount to intimidation, but all these doubts they resolved in favor of the defendants. There were, on the other hand, no doubts at all about the propriety of defendants' ends. The defendants themselves had dismissed the public policy question, submitting that " $[w]$ hether such combinations and agreements are on the whole beneficial or not to the public is a question not of law but of political economy as to which there will always be a difference of opinion"; $; 10$ but the court refused to accept this easy way out. Lord Bramwell maintained, on the contrary, that the public policy of free trade positively authorized such combinations: "It does seem strange," he wrote, "that to enforce freedom of trade, of action, the law

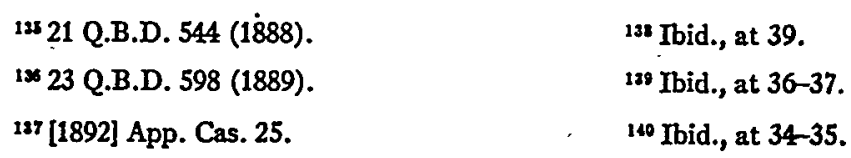


should punish those who make a perfectly honest agreement with a belief that it is fairly required for their protection." And he went on to suggest that combinations of employers should be given equal treatment with combinations of workmen:

I have always said that a combination of workmen, an agreement among them to cease work except for higher wages, and a strike in consequence, was lawful at common law; perhaps not enforceable inter se, but not indictable. The Legislature has now so declared. ${ }^{141}$

It followed that a combination of employers was lawful at common law. The law on combinations had by this time done its full circle: earlier in the century, unions had been legalized because combinations of masters were seldom if ever punished; by the end of the century, business combinations were held to be exempt from punishment because labor unions had been legalized.

By 1890, what there had been of English common law against monopolies had become quite weak. The common law against monopoly proper had been superseded by the Statute of Monopolies. The common law against forestalling had been abolished by the statute of 1844 . The common law against combinations of workmen and of masters had been overruled by the Trade Union Acts. The common law against contracts and combinations in restraint of trade alone remained in force, but it was governed by principles that condoned more than they prohibited. If monopolies were to be restrained, the common law would have to change its direction again, or legislation would have to remedy its weakness.

Legislation toward this end was provided in America, first by the antitrust laws of several states, and in 1890, by the Sherman Act. Such legislation had a firmer foundation in the United States than in England, because American common law in 1890 still contained provisions that had been struck from the English common law by statutes which had no legal effect here. Thus the common law against forestalling and engrossing was still in force in the United States; it could be made to serve purposes for which it had not been originally intended, and it was made the basis for section 2 of the Sherman Act, which prohibits "monopolizing."142 Similarly, labor unions were not exempted from the American common law on

141 Tbid., at 47 .

${ }^{142}$ Adler, Monopolizing at Common Law and under Sec. II of the Sherman Antitrust Act, 31 Harv. L. Rev. 246 (1917). 
combinations, and therefore the prohibition of combinations in section 1 of the Sherman Act could be used against certain activities of unions. But the Sherman Act went far beyond the common law when it authorized injured persons to sue, and the Attorney General to indict violators of the Act, making it possible to enforce competition actively. The Act was therefore much more an innovation than its authors realized. It did not, as they thought, merely declare the common law. It can almost be said to have helped create the common law, insofar as its authors' convictions helped spread the belief that the common law always expressed as much antagonism to monopoly as they wrote into the Sherman Act. 